
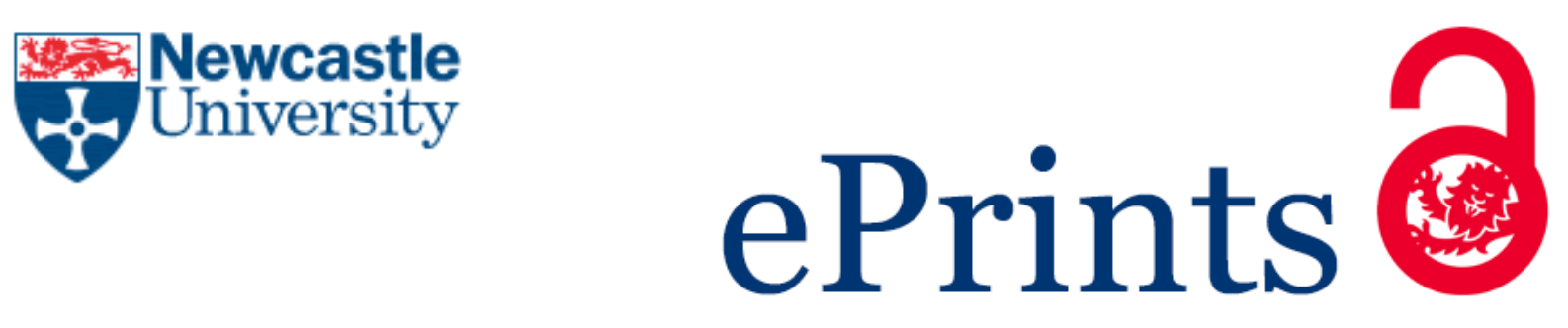

Urge-Vorsatz D, Rosenzweig C, Dawson RJ, Sanchez Rodriguez R, Bai X, Barau AS, Seto KC, Dhakal S.

Locking in positive climate responses in cities.

Nature Climate Change 2018, 8, 174-175

\title{
Copyright:
}

This is the authors' accepted manuscript of an article that has been published in its final definitive form by Nature Publishing Group, 2018

DOI link to article:

https://doi.org/10.1038/s41558-018-0100-6

Date deposited:

$14 / 03 / 2018$

Embargo release date:

27 August 2018 
Earth and environmental sciences / Environmental social sciences / Climate-change impacts

[URI /704/844/2739]

Earth and environmental sciences / Climate sciences / Climate change / Climate-change mitigation [URI /704/106/694/682]

Scientific community and society / Business and industry / Engineering / Civil engineering [URI /706/703/166/986]

\section{Locking-in positive climate responses in cities}

Diana Ürge-Vorsatz*, Cynthia Rosenzweig, Richard J. Dawson, Roberto Sanchez, Xuemei Bai, Aliyu Salisu Barau, Karen C. Seto, Shobhakar Dhakal

\section{* Corresponding author}

Diana Ürge-Vorsatz* ${ }^{*}$, Department of Environmental Sciences and Policy, Central European University, Budapest, Hungary $\mathrm{H}-1029$

Cynthia Rosenzweig, NASA Goddard Institute for Space Studies, New York, NY, 10591 USA

Richard J. Dawson, School of Engineering, Newcastle University, Newcastle-upon-Tyne, NE1 7RU, United Kingdom.

Roberto Sanchez Rodriguez, Department of Urban and Environmental Studies, El Colegio de la Frontera Norte, Tijuana, Mexico

Xuemei Bai, Fenner School of Environment and Society, Australian National University, Canberra, ACT 2601, Australia

Aliyu Salisu Barau, Department of Urban and Regional Planning, Bayero University Kano, Nigeria Karen C. Seto, Yale University, School of Forestry and Environmental Studies, New Haven, CT 06511, USA

Shobhakar Dhakal, School of Environment, Resources and Development, Asian Institute of Technology, Klong Luang, Pathumthani, Thailand 12120. 


\section{Well-intended climate actions are confounding each other. Cities must take a strategic and integrated approach to lock into a climate-resilient and low-emission future.}

Cities are home to many of the world's population and are key actors in climate mitigation and adaptation efforts. Many have stepped forward to show climate leadership but it is not clear whether urban strategies for adaptation constrain or facilitate mitigation, and vice versa. Efforts to understand, develop and implement adaptation and mitigation strategies typically operate in silos, with limited interaction. Despite the increased prevalence and ambition of city-level mitigation and adaptation plans, there are few efforts aiming at creating synergies or avoiding trade-offs between them.

Moreover, climate responses in cities are particularly vulnerable to the inertia built into certain infrastructures, technologies, institutions, and behavioural norms. These can create path dependencies that constrain the effectiveness of mitigation or adaptation actions for long periods, creating what we refer to as a carbon lock-in. ${ }^{1}$

Present and near-term actions that restrict our ability to drastically curb future emissions for long periods have new significance in the context of the urgency created by the Paris Agreement to limit global warming to well below $2^{\circ} \mathrm{C}$.

Here we argue that cities need to better integrate urban strategies for mitigation and adaptation to climate change, and consider the lock-in risks of their climate responses. Analyzing lock-in inherent in mitigation actions and adaptation pathways can strengthen opportunities to create synergies and reduce trade-offs between these responses, which have been poorly integrated in research and practice thus far. We present two frameworks that can help cities design strategies that maximize synergies and lock in low-emission, resilient development pathways.

\section{Interdependency between adaptation and mitigation}

The interdependencies of climate adaptation and mitigation measures are deep-seated in urban areas, where they play out through land use, infrastructure and the built environment, individual behaviour and policy. ${ }^{2}$ The sheer number of actions and the subtlety of many of the interactions coupled with a siloed approach to delivering climate action leads to unintended outcomes - synergies with magnified positive effects at times, but often unforeseen negative impacts elsewhere - extending into the future. ${ }^{3,4}$

An overview of classes of adaptation and mitigation actions and whether these can create synergies or trade-offs is presented in Figure 1. For example, high-efficiency buildings with solar heating tanks improve adaptation to warmer urban centers but also mitigate emissions through saving and generating energy. Green roofs synergistically reduce both urban heat islands and building energy use. Urban planning can also create synergies. In Helsinki, Finland, the district heating and cooling system uses recycled wastewater and waste energy to improve energy efficiency for summer cooling, while also reducing risk of power outage during periods of peak demand. ${ }^{5}$ Replanting of trees in Colombo, Sri Lanka is helping to protect biodiversity, provide flood protection to infrastructure, and increase carbon sequestration. ${ }^{6}$ Figure 1 indicates that more potential synergies arise from urban heat island and disaster risk reduction as well as new construction techniques, and that tradeoffs are more common in urban energy and transportation shifts.

Conversely, increasing urban density may reduce transportation energy use, but can increase flood risks and intensify urban heat island effects. ${ }^{7,8}$ In the city of Jena, Germany, high-density design resulted in greater energy and transport efficiency and improved waste management, though at the cost of green space for urban cooling. ${ }^{9}$ The long life span of urban form prolongs these effects. The underlying 
mechanisms of these trade-offs or synergies can be universal, but policy choices can and need to be context-dependent, based on a careful weighing of local issues, priorities, and goals.

\section{Interdependencies exacerbated by lock-in risks}

A well-designed climate strategy needs to focus on choices that avoid locking into high-emission pathways and low-resilience urban futures. Adaptation and mitigation actions in cities are particularly prone to lockin due to the longevity of land-use decisions and infrastructure choices, which may shape urban emission pathways and resilience for decades or centuries to come. For example, recognizing the large share of heating and cooling energy use in their emissions portfolio, many cities in the Global North started to offer subsidies to accelerate energy retrofits. However, these are usually small sums per building and thus result in only $10-30 \%$ thermal energy savings as opposed to the $70-90 \%$ possible through whole-building, systemic solutions. ${ }^{10}$

The dominant paradigm for urban mitigation strategies is to prioritise investment in "low-hanging fruit". However, easy investments with fast returns, such as boiler replacement, can prevent holistic/systemic, deep mitigation opportunities, such as a whole-building retrofit that becomes much less financially viable after a new boiler. Avoiding this $40-80 \%$ building thermal-energy use lock-in would require a fundamentally different approach to traditional energy efficiency incentives through coordinated, strategic actions and innovative financing.

Lock-in can also be positive. Eastern European cities maintain public transport as the dominant means of urban mobility. This results in much lower transport emissions decades after communism, a legacy of centrally planned infrastructure and prevailing norms.

In many parts of urban Africa and Asia there are opportunities to escape the negative carbon lock-in associated with developed world cities through investments in clean energy and decoupling from national grids. Access to energy is often limited and unreliable in many cities. Electricity provision through subsidies for minimally energy-intensive urban infrastructure and devices, e.g., portable solar panels and other locally generated renewable energy sources, can reduce the need for high-emission central generation capacities and high-investment power transmission infrastructure.

It is therefore crucial that cities start consistently considering the lock-in implications of their climate responses when designing their adaptation and mitigation strategies. Rapidly urbanizing cities in the developing world especially have the opportunity to leapfrog the carbon-intensive and ecologically destructive development path of the past, as they address challenges associated with informality and evolving governance structures. ${ }^{11}$

\section{Identifying, characterising and managing urban lock-in}

While there is abundant literature that conceptualises the problem of negative lock-in, identifying the diverse concrete lock-in risks in urban areas, and actions that can create a positive lock-in, is a major knowledge gap. ${ }^{1}$ For instance, there was not one single submission to the largest cities and climate change conference to date, the IPCC 2018 Cities and Climate Change Science Conference, that mentioned either lock-in or path dependence. Building on the key mitigation and adaptation strategies identified in the previous section and using the characterisation of lock-in types in Seto et al (2015), Tables 2 and 3 propose a framework for how the concrete lock-in risks and opportunities can be identified in specific urban areas, for mitigation and adaptation, respectively. The entries in the tables suggest examples of relevant lock-in 
risks and opportunities, but they need to be augmented by strategies for specific cities. They highlight that the same phenomenon sometimes can be turned from negative into positive lock-in.

\section{Avoiding trade-offs and locking in synergies}

Choices about adaptation and mitigation made today in cities will have a long-lasting impact for decades and centuries to come. To assume that one could design cities far in advance, or that cities would develop as designed, would be to misunderstand the nature of cities. Yet, avoiding negative lock-ins and catalyzing positive ones will require strategically planned action that is embedded alongside other urban development processes, and sustained through continuous review and evaluation of lock-in risks and opportunities.

Limited understanding of lock-in risks and opportunities represents a considerable gap in our knowledge, yet it has disproportionately significant practical implications for tackling climate change, exacerbated by rapid urbanization in many regions and the urgency of climate action to meet the Paris Agreement. Interdisciplinary research is urgently needed to better understand the nature and extent of lock-in characteristics, assess their implications for mitigation and adaptation actions, and develop new tools and business models that will enable cities to lock-in to positive climate responses and more importantly, their implementation.

\section{Acknowledgements}

The views represent those of the authors, who are part of the Scientific Steering Committee for the IPCC's 2018 Cities and Climate Change Science Conference, and not the IPCC. We thank Greg Reppucci for research support. 
Figure 1. Key interactions between urban mitigation and adaptation strategies. Adaptation strategies ( $\mathrm{x}$ axis) are colour coded to be consistent with a portfoliobased approach to urban adaptations. In the portfolio approach, adaptation strategies are consistent with Policies (blue), Community-based Adaptations (purple), Engineering Systems (orange), and Ecosystem-based Adaptations (green) ${ }^{12}$. Cells rate the strength of the interaction: -- (dark red): strong trade-off; - (light red): some trade-off; blank: no substantial trade-off or synergy; + (light green): some synergy; ++ (dark green): strong synergies.

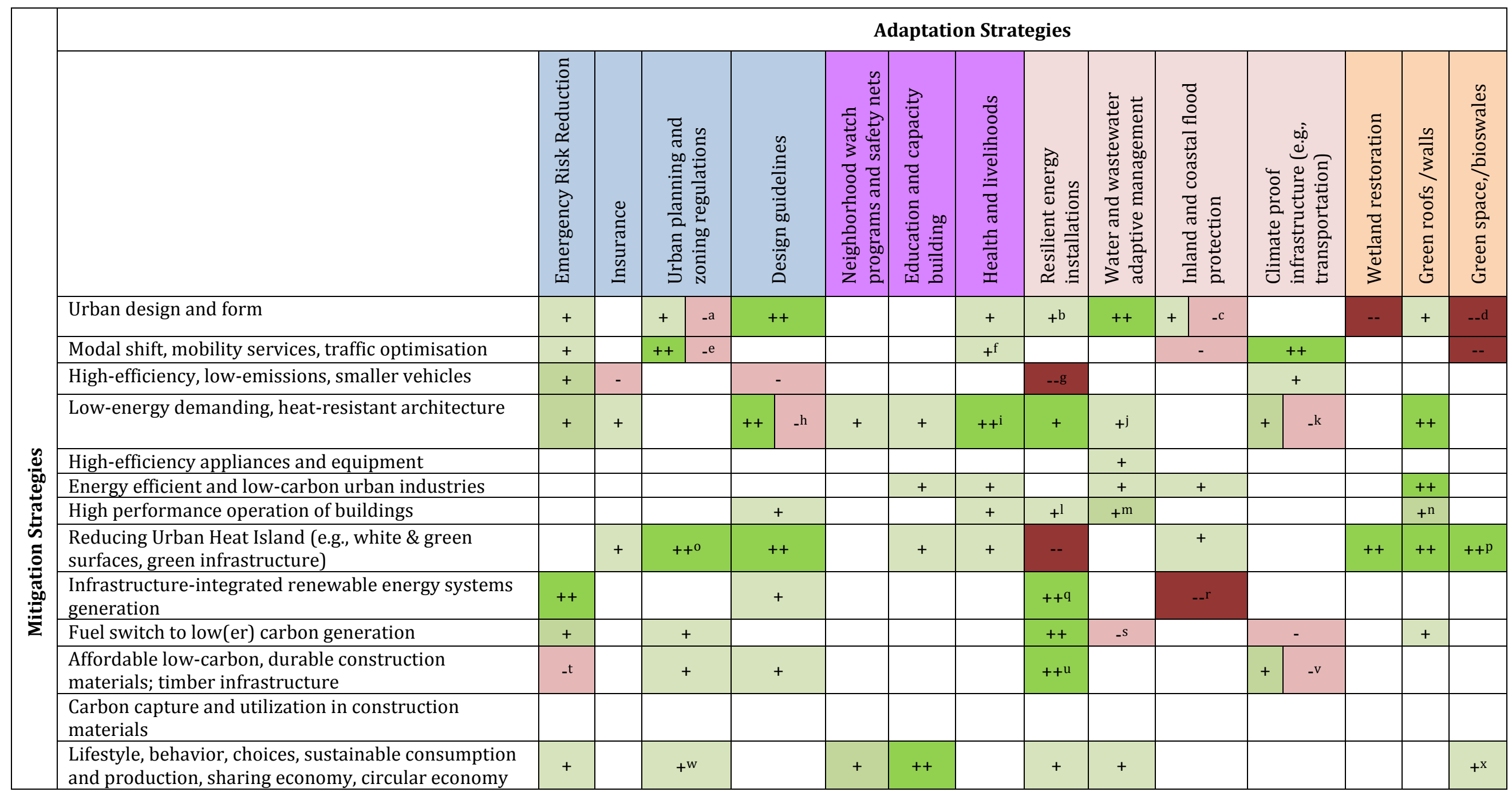


a Urban design for optimised adaptation and mitigation may coincide or compromise each other

b Building orientation, height, and spacing can help reduce need for cooling units ${ }^{4}$

c Flood protection may compromise urban design best serving mitigation purposes

$\mathrm{d}$ Maximizing compact urban design can reduce green space areas

e Urban designs best serving disaster risk reduction or adaptation needs may compromise the energy efficiency of the transport system

f Traffic optimization results in improved air quality; modal shift typically results in more activity, i.e. health gains

$\mathrm{g}$ Increased vehicular air conditioning will increase transport emissions

${ }^{\mathrm{h}}$ In heat prone regions design guidelines may prioritise the availability of mechanical cooling to reduce health risks, exacerbating emissions

i Very high efficiency buildings with heat recovery ventilation have major health and welfare benefits

j High-efficiency buildings often also manage water resources efficiently

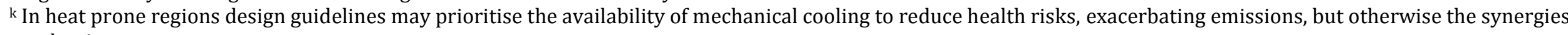
are dominant

${ }^{1}$ High-performance operation of buildings will increase the efficiency of mechanical cooling

${ }^{m}$ High performance operation typically also extends to better water management

$\mathrm{n}$ Green roofs will improve energy efficiency and operation of building.

o Enhances climate security resilience against extreme events

$\mathrm{p}$ Green space, will reduce urban heat islands, reduce risk of flooding

q Renewable energy reduces risk of power loss during extreme events

$\mathrm{r}$ Energy dependency on pumping water from flooding

s Some small-scale energy generation technologies require water resources

$\mathrm{t}$ Timber infrastructure may be less resilient to disasters than conventional ones

u Utilizing lightweight construction and phase-change materials (PCM), solar heat can be absorbed by PCM, in turn improving thermal regulation of building while also reducing energy, heating, cooling ${ }^{13}$

v Climate proof infrastructure could utilise timber; in other cases it needs to rely on concrete

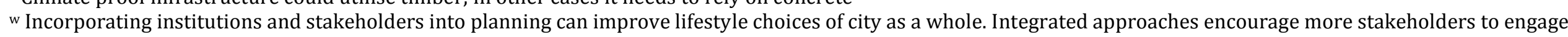

in the project, as multiple sectors and institutions are impacted by the adaptation and mitigation efforts ${ }^{14}$

${ }^{x}$ Experiencing biodiversity has been proven to improve life quality and environmental consciousness 
Figure 2. Infrastructural, institutional and behavioural lock-in mechanisms for key mitigation strategies. Colour coding: red: negative lock-in; green: positive lock-in; orange: can be both positive or negative lock-in. Shades represent the strength of the lock-in.

\begin{tabular}{|c|c|c|c|c|c|}
\hline Key urban mitigation strategy & \multicolumn{2}{|c|}{ Infrastructural lock-in } & Institutional lock-in & \multicolumn{2}{|c|}{ Behavioural lock-in } \\
\hline Urban design, land-use planning, relocation & \multicolumn{2}{|c|}{$\begin{array}{l}\text { Urban form, structure and density; } \\
\text { utility networks }\end{array}$} & $\begin{array}{l}\text { Urban decision-making not able to } \\
\text { plan for long-term benefits }\end{array}$ & \multicolumn{2}{|c|}{$\begin{array}{l}\text { Preference for low to medium density } \\
\text { parts of the city }\end{array}$} \\
\hline $\begin{array}{l}\text { Modal shift, shared mobility, mobililty services, traffic } \\
\text { optimisation }\end{array}$ & $\begin{array}{l}\text { Public transport } \\
\text { infrastructure is } \\
\text { long-lasting }\end{array}$ & $\begin{array}{l}\text { Shared urban } \\
\text { mobility } \\
\text { schemes have } \\
\text { lower } \\
\text { investment } \\
\text { needs }\end{array}$ & $\begin{array}{l}\text { Incumbent industries oppose } \\
\text { transformational change }\end{array}$ & $\begin{array}{l}\text { Shared mobility } \\
\text { requires } \\
\text { behavioural } \\
\text { change; }\end{array}$ & $\begin{array}{l}\text { accepted public } \\
\text { \& non-motorised } \\
\text { transport locks } \\
\text { culture in }\end{array}$ \\
\hline High efficiency, low-emission, smaller vehicles & \multicolumn{2}{|c|}{$\begin{array}{l}\text { Charging points, autoservices } \\
\text { infrastructure may be lacking }\end{array}$} & $\begin{array}{l}\text { policies in favor of private versus } \\
\text { public transportation }\end{array}$ & \multicolumn{2}{|c|}{ Automobiles as status symbols } \\
\hline Low-energy demanding, resilient, cool architecture & \multicolumn{2}{|c|}{$\begin{array}{l}\text { High-performance buildings can have } \\
90 \% \text { lower emissions+ vs } \\
\text { conventional ones }\end{array}$} & $\begin{array}{l}\text { Financing challenges to many } \\
\text { "small" investments with long } \\
\text { payback }\end{array}$ & \multicolumn{2}{|c|}{$\begin{array}{l}\text { Resistance to ventilation systems, } \\
\text { opening windows }\end{array}$} \\
\hline High-efficiency equipment and building operation & \multicolumn{2}{|c|}{ [relatively short lifetimes] } & & \multirow{2}{*}{\multicolumn{2}{|c|}{$\begin{array}{l}\text { Cultures favoring certain construction } \\
\text { aesthetics }\end{array}$}} \\
\hline Reducing UHI (incl. white \& green surfaces, etc) & \multicolumn{2}{|c|}{$\begin{array}{l}\text { Lack of space for urban greening. } \\
\text { availability of construction materials } \\
\text { with high albedo }\end{array}$} & $\begin{array}{l}\text { Poor and outdated building codes } \\
\text { and regulations }\end{array}$ & & \\
\hline $\begin{array}{l}\text { Infrastructure-integrated renewable energy systems } \\
\text { generation }\end{array}$ & \multicolumn{2}{|c|}{$\begin{array}{l}\text { Existing infrastructure may limit } \\
\text { opportunities }\end{array}$} & $\begin{array}{l}\text { Unfavorable financial incentives } \\
\text { and tax regimes; incumbents; }\end{array}$ & \multicolumn{2}{|c|}{$\begin{array}{l}\text { Lack of ability to judge potential } \\
\text { financial and other gains }\end{array}$} \\
\hline Fuel switch to low(er) carbon generation & \multicolumn{2}{|c|}{ Infrastructure is often not available } & $\begin{array}{l}\text { financial policies, incumbents; } \\
\text { stranded assets }\end{array}$ & \multicolumn{2}{|c|}{$\begin{array}{l}\text { High, or perceived higher cost of lower } \\
\text { carbon technologies }\end{array}$} \\
\hline $\begin{array}{l}\text { Affordable low-carbon, durable construction } \\
\text { materials; timber infrastructure }\end{array}$ & \multicolumn{2}{|c|}{$\begin{array}{l}\text { Alternative utilization of biomass } \\
\text { resources }\end{array}$} & $\begin{array}{l}\text { Market inertia; stranded assets } \\
\text { and incumbents }\end{array}$ & \multicolumn{2}{|c|}{ Lack of awareness; culture of taste } \\
\hline $\begin{array}{l}\text { Carbon capture and utilization in construction } \\
\text { materials }\end{array}$ & \multicolumn{2}{|c|}{ Inertia from existing industries } & Lack of adequate carbon pricing & \multicolumn{2}{|c|}{$\begin{array}{l}\text { Fear of losing jobs from innovations; } \\
\text { concern about potential risks }\end{array}$} \\
\hline $\begin{array}{l}\text { Lifestyle, behavior, sustainable consumption and } \\
\text { production, sharing economy, circular economy }\end{array}$ & \multicolumn{2}{|c|}{$\begin{array}{l}\text { Lack of choice of alternative } \\
\text { infrastructure }\end{array}$} & $\begin{array}{l}\text { Competition between states and } \\
\text { cities for regional prosperity }\end{array}$ & \multicolumn{2}{|c|}{$\begin{array}{l}\text { Resistance to change, long inertia in } \\
\text { cultures, norms and values }\end{array}$} \\
\hline
\end{tabular}


Figure 3. Infrastructural, institutional and behavioural lock-in mechanisms for key adaptation strategies. Colour coding: red: negative lock-in; green: positive lockin; orange: can be both positive or negative lock-in. Shades represent the strength of the lock-in.

\begin{tabular}{|c|c|c|c|}
\hline Key urban adaptation strategy & Infrastructural lock-in & Institutional lock-in & Behavioural lock-in \\
\hline Emergency risk reduction & Tidal barriers & Climate-specific policies & Evacuation fatigue \\
\hline Insurance & $\begin{array}{l}\text { (Lack of) incorporation of evolving } \\
\text { climate risks for infrastructure }\end{array}$ & Government & Time-scale mismatch \\
\hline Urban planning and zoning regulations & $\begin{array}{l}\text { Long-term infrastructure built with } \\
\text { outdated zoning guidelines }\end{array}$ & $\begin{array}{l}\text { Re-evaluate and update zoning } \\
\text { regulations as climate changes }\end{array}$ & $\begin{array}{l}\text { Short-term profit motivation for } \\
\text { developers }\end{array}$ \\
\hline Design guidelines & $\begin{array}{l}\text { Building placement and design can } \\
\text { significantly impact city heating }\end{array}$ & $\begin{array}{l}\text { Regular need to re-evaluate and } \\
\text { update design guidelines }\end{array}$ & $\begin{array}{l}\text { Design guidelines for adaptation are } \\
\text { used by architects and planners }\end{array}$ \\
\hline Neighborhood watch programs and safety nets & Lack of urban observatory facilities & $\begin{array}{l}\text { Government support for cooling } \\
\text { stations }\end{array}$ & $\begin{array}{l}\text { Caring community groups and } \\
\text { support for vulnerable populations }\end{array}$ \\
\hline Education and capacity building & Schools located in flood-prone areas & $\begin{array}{l}\text { Government support for resilient } \\
\text { job creation }\end{array}$ & $\begin{array}{l}\text { Education promotes resilient } \\
\text { behavior }\end{array}$ \\
\hline Health and livelihoods & $\begin{array}{l}\text { Infrastructural design impacts health } \\
\text { and wellbeing }\end{array}$ & $\begin{array}{l}\text { Human resource planning for heat } \\
\text { alerts }\end{array}$ & Green jobs \\
\hline Resilient energy installations & Generators and planned fuel supply & $\begin{array}{l}\text { Facility upgrades in capital } \\
\text { planning }\end{array}$ & $\begin{array}{l}\text { Homeowners adopting resilience } \\
\text { measures }\end{array}$ \\
\hline Water and wastewater adaptive management & $\begin{array}{l}\text { Long-lived operational facilities, e.g., } \\
\text { reservoirs, pipelines }\end{array}$ & $\begin{array}{l}\text { Embedded flexibility to alter policy } \\
\text { as new information comes to light }\end{array}$ & Demand-side modification \\
\hline Inland and coastal flood protection & Levees and berms & $\begin{array}{l}\text { (Lack of) multi-jurisdictional } \\
\text { coordination }\end{array}$ & Living in coastal flood-prone areas \\
\hline Climate-proof transportation and infrastructure & Long-lived urban systems & Choice of major mobility systems & Difficulty to shift habits \\
\hline Wetland restoration & Increases resilience to flooding & Wetland protection policies & Migration from flood-prone areas \\
\hline Green roofs/walls & Biophysical species requirements & Need for ongoing subsidies & Increasing awareness \\
\hline Green space/bioswales & $\begin{array}{l}\text { Green area designed with lack of } \\
\text { public inclusion }\end{array}$ & Maintenance costs & Recreational use \\
\hline
\end{tabular}




\section{References}

${ }^{1}$ Seto, K.C., Davis, S.J., Mitchell, R.B., Stokes, E.C., Unruh, G. and Ürge-Vorsatz, D. (2016). Carbon lock-in: Types, causes, and policy implications. Annual Review of Environment and Resources, 41, pp.425-452.

2 Dawson, R. J. (2011) Potential pitfalls on the transition to more sustainable cities ... and how they might be avoided, Carbon Management, 2(2):175-188 (doi:10.4155/cmt.11.8).

${ }^{3}$ Bai, X., Surveyer A., T. Elmqvist, F.W. Gatzweilerd, B. Guneralpe, S. Parnellf, A-H. Prieur-Richardg, P.

Shrivastavah, J. Gabriel S., M. Stafford-Smithj, J-P. Toussaintk, R. Webb. (2016). Defining and advancing systems approach for sustainable cities. Current Opinion in Environmental Sustainability 23:69-78.

${ }^{4}$ Grafakos, S. et al. (2018). Integrating mitigation and adaptation: Opportunities and challenges. In Rosenzweig, C., W. Solecki, P. Romero-Lankao, S. Mehrotra, S. Dhakal, and S. Ali Ibrahim (eds.), Climate Change and Cities: Second Assessment Report of the Urban Climate Change Research Network. Cambridge University Press. New York. 101-138.

${ }^{5}$ Tsupari, E., Arponen, T., Hankalin, V., Kärki, J. and Kouri, S., 2017. Feasibility comparison of bioenergy and CO2 capture and storage in a large combined heat, power and cooling system. Energy, 139, pp.1040-1051 ${ }^{6}$ Grafakos, S., Sharma, S., and Gianoli, A. (2018). Pilot Application of Sustainability Benefits Assessment Methodology in Colombo Metropolitan Area, Sri Lanka. UCCRN ARC3.2 Case Study Docking Station. In Rosenzweig, C., W. Solecki, P. Romero-Lankao, S. Mehrotra, S. Dhakal, and S. Ali Ibrahim (eds.), Climate Change and Cities: Second Assessment Report of the Urban Climate Change Research Network. Cambridge University Press. New York. 112-114.

7 Caparros-Midwood D, Barr S, Dawson RJ (2017) Spatial Optimization of Future Urban Development with regards to Climate Risk and Sustainability Objectives, Risk Analysis, 37(11): 2164-2181 (doi: 10.1111/risa.12777).

${ }^{8}$ Raven, J., et al. (2018). Urban planning and design. In Rosenzweig, C. W. Solecki, P. Romero-Lankao, S. Mehrotra, S. Dhakal, and S. Ali Ibrahim (eds.), Climate Change and Cities: Second Assessment Report of the Urban Climate Change Research Network. Cambridge University Press. New York. 139-172.

${ }^{9}$ Gebhardt, O. (2018). Jena Germany Adaptation Strategy as an Essential Supplement to Climate Change Mitigation Efforts. UCCRN ARC3.2 Case Study Docking Station. In Rosenzweig, C., W. Solecki, P. Romero-Lankao, S. Mehrotra, S. Dhakal, and S. Ali Ibrahim (eds.), Climate Change and Cities: Second Assessment Report of the Urban Climate Change Research Network. Cambridge University Press. New York. 115-118.

10 Ürge-Vorsatz, D., K. Petrichenko, Staniec, M., Eom, J. (2013). Energy use in buildings in a long-term perspective. Current Opinion in Environmental Sustainability 5(2):141-151.

${ }^{11}$ O'Donoghue, S. and Roberts, D. (2018) Synergies, Conflicts, and Tradeoffs between Mitigation and Adaptation in Durban, South Africa. UCCRN ARC3.2 Case Study Docking Station. In Rosenzweig, C., W. Solecki, P. RomeroLankao, S. Mehrotra, S. Dhakal, and S. Ali Ibrahim (eds.), Climate Change and Cities: Second Assessment Report of the Urban Climate Change Research Network. Cambridge University Press. New York. 111-112.

12 Rosenzweig, C. et al.. (2018). Pathways to urban transformation. In Rosenzweig, C., W. Solecki, P. RomeroLankao, S. Mehrotra, S. Dhakal, and S. Ali Ibrahim (eds.), Climate Change and Cities: Second Assessment Report of the Urban Climate Change Research Network. Cambridge University Press. New York. 3-26.

${ }^{13} \mathrm{Han}, \mathrm{J}$., Wang, X., and Chen, D., (2018). Adapting summer overheating in light constructions with phase-change materials in Melbourne, Australia. UCCRN ARC3.2 Case Study Docking Station. In Rosenzweig, C., W. Solecki, P. Romero-Lankao, S. Mehrotra, S. Dhakal, and S. Ali Ibrahim (eds.), Climate Change and Cities: Second Assessment Report of the Urban Climate Change Research Network. Cambridge University Press. New York. 154-155 ${ }_{14}$ Zambrano, C. and Enriquez, D. (2018). Integrating Mitigation and Adaptation in Climate Action Planning in Quito, Ecuador. UCCRN ARC3.2 Case Study Docking Station. In Rosenzweig, C., W. Solecki, P. Romero-Lankao, S. Mehrotra, S. Dhakal, and S. Ali Ibrahim (eds.), Climate Change and Cities: Second Assessment Report of the Urban Climate Change Research Network. Cambridge University Press. New York. 122-123 